\title{
TEKNOLOGI 3D DALAM PROSES PEMBUATAN KOMIK
}

\author{
Johanes Baptista Permadi \\ Jurusan Desain Komunikasi Visual, Fakultas Komunikasi dan Multimedia, BINUS University \\ Jln. K.H. Syahdan No. 9, Kemanggisan, Jakarta Barat 11480 \\ johanesbp@yahoo.com
}

\begin{abstract}
Comic has been people's favorite since 1930. As the growth of years and technology, the demands in designing comic were also increasing. To fulfill the demands, comic authors spent their times to draw so that they have no time to discover other element besides technical. Therefore, it is important if the comic author helped by $3 D$ technology to accelerate technical process so that the comic authors will get extra time to develop other elements like concept and story. Data is gathered from interviews with both semi-professional and professional comic authors who are having problems being solved. Solving problems are conducted by using $3 D$ software to draw picture of distorted space. And then two semi-professional comic authors will try to draw distorted space in tracing the picture from $3 D$ software to see how many times needed to draw hard part traditionally.
\end{abstract}

Keywords: technology, 3D, comic

\begin{abstract}
ABSTRAK
Komik sudah digemari oleh masyarakat sejak tahun 1930. Seiring dengan berkembangnya zaman dan teknologi, tuntutan untuk pembuatan komik pun meningkat. Untuk memenuhi tuntutan tersebut, tidak sedikit komikus yang menghabiskan waktunya untuk menggambar dengan benar sehingga sang komikus tidak lagi memiliki waktu untuk mengulik unsur penting lainnya selain segi teknis. Oleh karena itu akan sangat berguna sekali apabila sang komikus dapat terbantu dengan menggunakan teknologi 3D untuk mempercepat proses teknis sehingga sang komikus bisa mendapatkan waktu lebih untuk mengolah unsur penting lain seperti konsep dan cerita. Data diperoleh dari pembicaraan kepada beberapa komikus baik yang sudah profesional, maupun semi profesional, dimana para komikus ini sudah secara langsung mengalami sendiri permasalahan yang akan dipecahkan. Pemecahan masalah dilakukan dengan menggunakan bantuan software 3D untuk membuat gambar sebuah ruangan yang terdistorsi, Lalu dua orang calon komikus profesional akan mencoba menggambar ruangan terdistorsi tersebut dengan cara men-trace hasil dari software $3 D$ untuk melihat seberapa banyak waktu yang diperlukan untuk menggambar bagian yang seharusnya sulit apabila dikerjakan secara tradisional.
\end{abstract}

Kata kunci: teknologi, 3D, komik 


\section{PENDAHULUAN}

Komik merupakan sebuah buku cerita bergambar yang diminati banyak orang. Sejarah komik di Indonesia sendiri sudah dimulai pada tahun 1930an, yaitu dengan munculnya sebuah komik strip berjudul Kho Wang Gie atau Sopoiku di surat kabar Sin Po. Komik strip yang dimulai dari tahun 1931 ini berlangsung selama 30 tahun dan berakhir saat surat kabar Sin Po ditutup pada tahun 1960. Kejayaan komik Indonesia pun tidak berakhir begitu saja. Penerus-penerus komik strip seperti R.A. Kosasih mulai menerbitkan komik dengan format buku yang berjudul Sri Asih, dan dilanjutkan dengan komik yang berjudul Mahabarata dan Ramayana.

Pada tahun 1968 Komik Indonesia mengalami zaman keemasan, dimana banyak orang yang menggemari komik, dan honor komikus pada saat itu mencapai 100-150 ribu rupiah per 64 lembar. Saat itu proses pembuatan komik masih cukup sulit, belum didukung dengan teknologi. Konsistensi gambar antar panel dalam komik menjadi tantangan, proses penyuntingan gambar yang terbatas, dan kemampuan memundurkan proses yang pada zaman sekarang ini dikenal dengan istilah Undo tidak memungkinkan pada saat itu karena semuanya masih dilakukan secara tradisional.

Namun pada masa sekarang ini, proses pembuatan komik menjadi lebih mudah karena dibantu dengan teknologi. Dengan teknologi 3D, komikus tidak lagi menghabiskan banyak waktu untuk menggarap hal-hal yang bersifat teknis seperti perspektif, proporsi, penentuan sudut pandang, dan pencahayaan. Walaupun demikian, dengan adanya teknologi yang membantu di bagian-bagian ini bukan berarti seorang komikus tidak perlu mempelajari bagaimana membuat perspektif, proporsi dan sebagainya karena hal-hal tersebut tidak hanya berupa sekedar looks yang membuat visual lebih kaya, namun juga memiliki konsep dan makna tersendiri.

\section{METODE}

Permasalahan diidentifikasi setelah mengadakan pembicaraan dengan komikus-komikus Indonesia yang belum memasuki level profesional. Hasil pembicaraan tersebut kurang-lebih berkisar antara kesulitan sang komikus untuk menghasilkan gaya gambar yang konsisten dari panel ke panel sampai halaman ke halaman. Beberapa dari komikus memiliki kelebihan dalam pengkarakteran, namun memiliki kelemahan pada saat menggambar perspektif, latar belakang, atau benda-benda yang sifatnya hard surface. Di saat yang sama, komikus lain memiliki kelebihan dan kekurangan yang berbeda, ada yang kuat pada saat menggambar perspektif dan latar belakang, namun lemah dalam menggambar karakter, dan sebagainya.

Tidak konsisten dalam menggambar adalah suatu hal yang alami untuk manusia, namun dalam dunia visual, terlebih lagi untuk bidang komik, konsistensi visual harus dipertahankan. Akan sangat tidak enak dilihat apabila sang tokoh dari komik tersebut terlihat berbeda setiap beberapa halaman atau panelnya. Kesulitan lain yang dialami komikus adalah bagaimana caranya membuat sebuah komik yang baik secara visual, berbobot secara cerita, dan konsepnya jelas, namun harus menepati deadline yang relatif tergolong ketat. Kebanyakan komikus yang belum memiliki banyak pengalaman lebih menghabiskan waktu untuk menggarap konsistensi karakter, perspektif yang benar, proporsi, latar belakang, sudut pandang, pencahayaan, dan segala yang bersifat lebih teknis. Karena waktu banyak dihabiskan untuk hal-hal teknis ini, alhasil faktor cerita dan konsep menjadi kurang terolah, hal ini dapat menyebabkan alur cerita dari komik tersebut kurang jelas, terlalu cepat, atau kurang menghasilkan impact bagi pihak pembaca. 
Untuk dapat memperkuat cerita dan konsep dalam sebuah komik, cara yang paling memungkinkan adalah dengan mempercepat proses teknis dengan bantuan software 3D. Karena software 3D dapat menghasilkan perspektif yang terbentuk berdasarkan lensa yang ditentukan, ditambah dengan kemampuan untuk menghitung letak jatuhnya pencahayaan berdasarkan sumber cahaya yang telah ditentukan, sang komikus hanya tinggal melakukan tracing dari hasil kalkulasi yang dikenal dengan istilah rendering pada software 3D. Untuk mengetahui apakah teknik ini dapat digunakan, dua orang calon komikus profesional akan mencoba untuk menggambar suatu setting ruangan dengan distorsi tinggi, seperti halnya ruangan tersebut difoto dengan lensa fish eye. Dengan bantuan software 3D untuk membuat konstruksi ruangan, menata props dan mengatur pencahayaan, dibutuhkan waktu kurang lebih 3 sampai 4 jam.

\section{HASIL DAN PEMBAHASAN}

Kedua orang calon Komikus profesional tersebut hanya perlu men-trace dan memberi efek pencahayaan berdasarkan hasil render dari software 3D. Satu dari komikus tersebut berhasil menyelesaikan gambar tersebut dalam waktu 40 menit, sedangkan yang lain berhasil menyelesaikannya dalam waktu 30 menit. Berikut adalah hasil render 3D yang dijadikan patokan dalam menggambar, dan hasil gambar masing-masing calon komikus profesional tersebut.

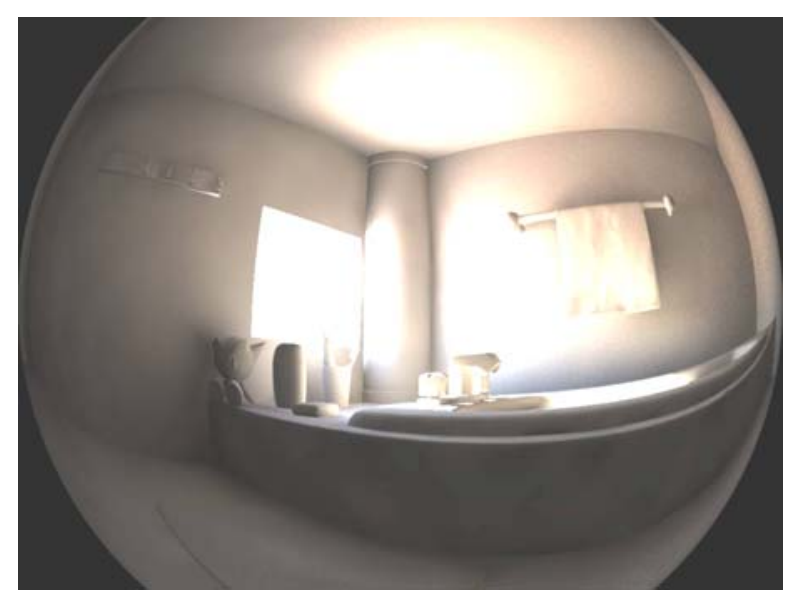

Gambar 1 Hasil Render dari Software 3D

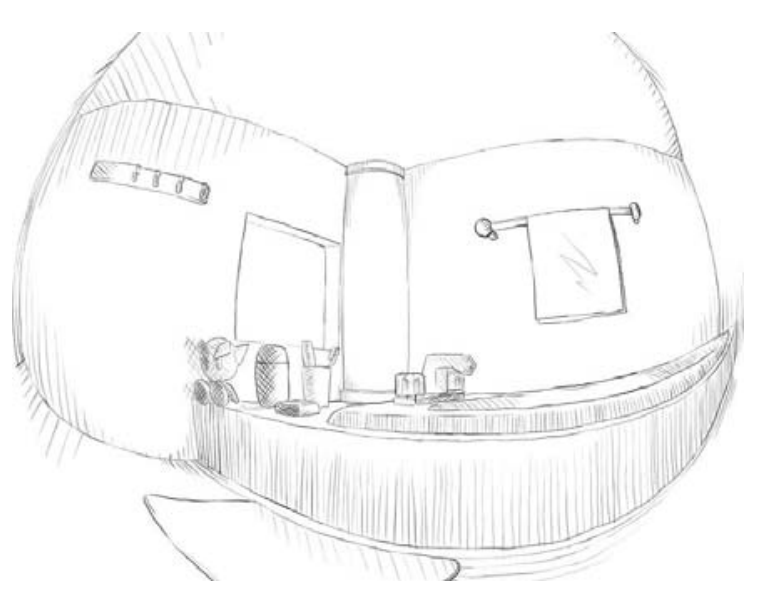

Gambar 2 Hasil Trace dari Komikus Pertama 


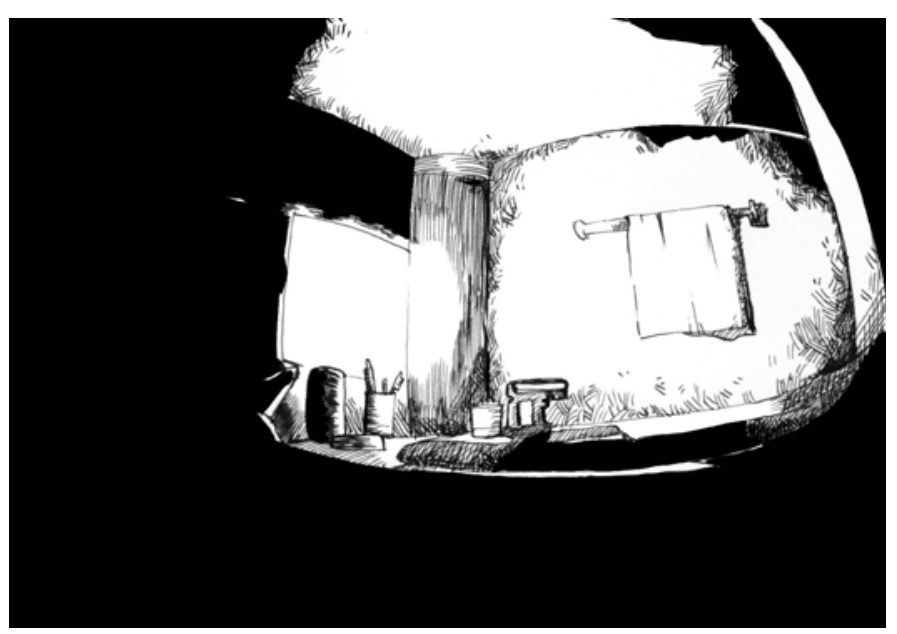

Gambar 3 Hasil Trace dari Komikus Kedua

Dari hasil percobaan yang dilakukan, dapat disimpulkan teknologi 3D dapat sangat membantu para komikus untuk bisa menanganti permasalahan teknis dalam proses pembuatan komik. Selain konsistensi dapat dipertahankan, akurasi dalam perspektif, jatuhnya cahaya, dan distorsi lensa juga dapat dibuat tanpa memakan waktu yang cenderung lama. Bayangkan berapa waktu yang dapat dihemat apabila ada 10 panel komik yang memerlukan perspektif yang akurat, atau pencahayaan yang benar, dan sebagainya.

Selain akurat dan realistik, tidak tertutup pula kemungkinan bagi sang Komikus untuk dapat meng-exaggerate sudut pandang tersebut. Hasil render dapat dikatakan realistik, tetapi bukan berarti sang komikus harus mengikuti hasil tersebut secara mutlak. Adalah hak para komikus untuk menaruh sentuhan khas masing-masing pada panel yang digambar. Sentuhan gaya visual yang unik, ataupun berbagai macam bentuk exaggeration yang seringkali dapat membuat sebuah komik menjadi unik dan dapat diingat oleh pembacanya.

Salah seorang calon komikus yang melakukan test sebelumnya memberikan tanggapan bahwa tidak semua komikus bisa menggunakan software 3D. Memang dapat dimaklumi bahwa ini adalah suatu kendala yang membuat komikus yang bersangkutan harus belajar lagi tentang software dan teknologi 3D ini. Walaupun demikian, sumber-sumber ilmu dan pusat pembelajaran yang berkaitan dengan 3D tidaklah sedikit, dan untuk menggunakan software 3D hanya sebagai alat bantu dalam menggambar komik, cukup untuk menguasai software 3D sampai tingkat dasar saja.

Walaupun demikian, ada kecenderungan bagi para komikus untuk menjadi tergantung akan software 3D karena kemudahannya untuk membuat sesuatu yang realistik dan akurat. Apabila seorang komikus menjadi tergantung dengan software 3D dan tidak pernah melatih sense perspektif, proporsi, pencahayaan, dan sebagainya secara tradisional, ada kemungkinan jika kemampuan sang komikus untuk membuat perspektif, proporsi, pencahayaan yang benar menurun karena terlalu terbiasa dengan men-tracing hasil render dari software 3D.

Penggunaan software 3D sebagai alat bantu yang sangat memudahkan juga dapat menyebabkan para calon komikus lainnya menjadi malas dalam belajar perspektif, proporsi, pencahayaan dan lain sebagainya. Terutama pada hal penempatan dan bentuk perspektif, serta pencahayaan memiliki makna yang lebih dalam daripada hanya sekedar look saja, misalnya bentuk perspektif apa yang harus dipakai agar si karakter terlihat lebih menarik daripada latar belakang, atau bagaimana cara mengarahkan mata pembaca ke suatu titik tertentu dalam sebuah panel komik. Atau misalnya dalam hal pencahayaan, bagaimana cara menempatkan jatuhnya bayangan agar si karakter 
terlihat misterius, gagah, atau mungkin terlihat licik, jahat, dan sebagainya. Apabila sang komikus tidak menguasai teori-teori mendasar tersebut, komik yang dihasilkan tidak akan dapat maksimal, walaupun dengan bantuan teknologi 3D.

\section{PENUTUP}

Penggunaan teknologi 3D dalam proses menggambar komik terbukti sangat membantu, terutama dalam penggambaran sudut pandang yang sulit dan mustahil untuk diselesaikan dalam waktu cepat apabila dikerjakan secara tradisional. Walaupun demikian, karena ada kecenderungan untuk menjadi tergantung pada teknologi 3D dan membuat kemampuan diri sendiri menjadi tidak terasah, maka sangat disarankan untuk menggunakan teknologi 3D hanya pada bagian yang sangat sulit saja.

\section{DAFTAR PUSTAKA}

D'Amelio, J. (1984). Perspective drawing handbook. Dover Publications.

Hidayah, A. (2008, April). Sejarah komik Indonesia: Buram dan bertahan. Koran Tempo. Diakses pada 20 January, 2011, dari MalangRaya Arsip Berita dan Informasi Regional: http://malangraya.web.id/2008/04/15/sejarah-komik-indonesia-buram-dan-bertahan/

Watson, E. W. (1993). Creative perspective for artists and illustrators. Dover Publications. 